UCC 504.5:635.8:664.8.022.7

DOI: $10.37128 / 2707-5826-2020-2-19$

\section{ANALYSIS OF THE EFFICIENCY OF USING THE CULINARY PROCESSING OF MUSHROOMS IN ORDER TO REDUCE THE CONCENTRATION OF HEAVY METALS IN THEM}

O.I. ВРАДІЙ, асистент,

Вінницький національний аграрний університет

The samples of mushrooms were collected in the forestry of the village Tyvriv and the town of Kalynivka, Vinnytsia and Kalynivka districts, in the conditions of Right-Bank Forest-Steppe of Ukraine. The studies of heavy metals concentration were performed in the scientific agrochemical laboratory of the Department of Ecology and Environmental Protection, the Faculty of Agronomy and Forestry at Vinnytsia National Agrarian University. The concentrations of $\mathrm{Cu}, \mathrm{Zn}, \mathrm{Pb}$ and $\mathrm{Cd}$ of the studied mushrooms were determined by the method of atomic absorption spectrometry after the dry mineralization. The research of the effect of culinary processing on the concentration of heavy metals in mushrooms were conducted according to the following scheme: 1 . The control: mushrooms, cleaned and washed with tap water; 2. Option 1: mushrooms soaked in tap water for 3 hours and boiled in it; 3. Option 2: mushrooms soaked in the water without mineral residue for 3 hours and boiled in it; 4. Option 3: mushrooms soaked in distilled water for 3 hours and boiled in it.

Summarizing the obtained results, it should be noted that the most effective way to reduce the concentration of lead and cadmium in mushrooms was the option of soaking and boiling mushrooms in the water without mineral residue. The most effective way to reduce the concentration of zinc and copper was Option 3, where distilled water was used. The influence of soaking and boiling mushrooms in different types of water is investigated. When soaking and boiling mushrooms in tap water for 3 hours, the concentration of zinc in them was found to decrease from 1.01 to 1.04 times, the concentration of copper - from 1.0 to 1.2 times, the concentration of lead from 1.09 to 1.16 times and the concentration of cadmium - from 1.08 to 1.2 times. When soaking and boiling mushrooms in the water without mineral residue, the concentration of zinc decreased from 1.01 to 1.04 times, the concentration of copper - from 1.16 to 1.25 times, the concentration of lead - from 1.8 to 2.0 times and the concentration of cadmium - from 1.75 to 2.0 times. When soaking mushrooms and boiling them in distilled water, the concentration of zinc decreased from 1.13 to 1.18 times, the concentration of copper - from 1.2 to 1.29 times, the concentration of lead - from 1.22 to 1.28 times and the concentration of cadmium - from 1.08 to 1.2 times.

Key words: mushrooms, concentration, zinc, copper, lead, cadmium, distilled water, water without mineral residue, tap water, boiling of mushrooms.

Tabl. 4. Fig. 4. Lit. 9. 
Setting the problem. Mushrooms have always been considered a valuable food product, and mushroom dishes are a favorite food of many peoples. This is not accidental, since they contain many organic and mineral compounds, similar in chemical composition to vegetables and products of animal origin [1, 2]. It is known that fresh mushrooms contain: $84-94 \%$ of water, $2-6 \%$ of nitrogenous substances (80\% of which are proteins), $1-3 \%$ of carbohydrates, $0.2-6.0 \%$ of fats, $0.6-1.0 \%$ of minerals, as well as vitamins A, B1, B2, C, D, PP [3-4].

The high content of chitin forms complexes with proteins, pigments and calcium salts. It differs significantly from vegetable fiber - cellulose and prevents the complete absorption of mushroom dishes during digestion. In the dry matter of mushrooms there are many proteins [5], the content of which often exceeds $40 \%$, that is, it is higher than in the seeds of peas and beans. The digestibility of fungal proteins is $54-85 \%$, that is, approximately the same as that of vegetable ones. The carbohydrate content in the dry matter of mushrooms can reach $70 \%$ and they are absorbed by 93-99\%. Such carbohydrates as Glycogen (animal starch), Trehalose, Glucose, Mycosis and Mannitol are dominated in mushrooms. These substances cause a pleasant sweet taste of mushrooms. Many species are characterized by the high content of carbohydrates in the dry matter. They are still little used, but they are widespread and suitable for saulting, in particular Russula Pers. (Lat.) and Lactarius resimus (Lat.). [7] Fatty substances of mushrooms (phosphatides, cholesterol and ergosterol) are absorbed by 92-97\%, and their content in the fruiting bodies is greater than in potatoes or other vegetables. In the fruiting bodies there are also extractive substances, carotene, pantothenic acid, enzymes and antibiotic substances, in addition to various mineral substances, in the content of which mushrooms are close to fruit [8-9].

The forestry products of vegetable origin, namely their harvesting is of great importance for the enterprises of the forest industry, providing people with food of high value. In particular, mushrooms and berries sometimes supplement people's diets, but there are also occasions when they serve staple foods, even on a par with bread, meat and vegetables.

Wild berries and edible mushrooms are mostly used for consumption without special processing. That is why the sanitary and hygienic quality of non-timber raw materials is a significant factor affecting its safety [5]. However, the content of heavy metals in the phytomass of representatives of Ukraine's wild flora, suitable for using as non-timber raw materials, has not been sufficiently studied. The bulk of the research is devoted to the characteristics of migration and accumulation of heavy metals in crops, while wild species remain outside the focus of scientists. Because of the intensification of technogenic and anthropogenic pressure on ecosystems, the number of areas suitable for the collection of environmentally friendly non-timber raw materials is sharply reduced.

The consumption of non-timber forest resources containing heavy metals can lead to adverse effects occurring in the human body. Therefore, the topic of finding ways to reduce the content of these substances in forestry products is very relevant. 
Analysis of recent researches and publications. The studies on the bioaccumulation of heavy metals in various types of phytocenoses are of considerable interest, since plants and mushrooms, as an autotrophic block of ecosystems, play an important role in the redistribution of chemical elements between individual components of the biosphere. The forest landscapes, as dominant geochemical regulators of cyclic mass flows of heavy metals at the global level, are of particular importance in this process [10-11].

The excessive concentrations of heavy metals in the environment, far exceeding the natural ones, can greatly affect the functioning of plants and mushrooms, reduce the biotic productivity of forests, impair their recreational potential and alter the quality of wood, which may affect its environmental safety. In the complex of researches on the biotic productivity, the study of the role of timber and non-timber forest resources in the biogeocenoses in relation to the migration and deposition of elements of the heavy metals group, especially in the area of technogenic loading, is an urgent and timely task. Its solution will allow finding the mechanisms of selective ability of forest species to absorb and accumulate heavy metals in tissues, and to remove them from circulation for a long time. The excessive concentrations of heavy metals can influence the course of physiological processes to some extent that is reflected in the change of the integral indicator of forest plants - phytomass. According to the literature, timber and non-timber forest resources respond to the environmental pollution by reducing their biotic productivity [12]. Therefore, the need to monitor the pollution of non-timber forest resources by heavy metals and to study the ways to improve their quality remains relevant.

Research methodology and conditions. The samples of mushrooms were collected in the forestry of the village Tyvriv and the town of Kalynivka, Vinnytsia and Kalynivka districts, in the conditions of Right-Bank Forest-Steppe of Ukraine. The studies of heavy metals concentration were performed in the scientific agrochemical laboratory of the Department of Ecology and Environmental Protection, the Faculty of Agronomy and Forestry at Vinnytsia National Agrarian University. The concentrations of $\mathrm{Cu}, \mathrm{Zn}, \mathrm{Pb}$ and $\mathrm{Cd}$ of the studied mushrooms were determined by the method of atomic absorption spectrometry after the dry mineralization $[13,14]$. The research of the effect of culinary processing on the concentration of heavy metals in mushrooms were conducted according to the following scheme: 1 . The control: mushrooms, cleaned and washed with tap water; 2 . Option 1: mushrooms soaked in tap water for 3 hours and boiled in it; 3. Option 2: mushrooms soaked in the water without mineral residue for 3 hours and boiled in it; 4. Option 3: mushrooms soaked in distilled water for 3 hours and boiled in it.

The purpose of the article is to study the efficiency of using the methods of culinary processing of mushrooms in order to reduce the content of heavy metals in them. 
Presenting the main material. The obtained results of the research showed a certain influence of soaking and boiling mushrooms in different types of water on the concentration of heavy metals in them (Table 1-4).

Zinc concentration in mushrooms, $\mathrm{mg} / \mathrm{kg}$

\begin{tabular}{|c|c|c|c|c|c|}
\hline Kind of mushrooms & MPC & $\begin{array}{c}\text { The } \\
\text { control }\end{array}$ & Option 1 & Option 2 & Option 3 \\
\hline Cantharēllus cibārius (Lat.) & 20 & 6.41 & 6.26 & 6.24 & 5.64 \\
\hline Gyroporus cyanescens (Lat.) & 20 & 7.09 & 6.97 & 6.95 & 6.1 \\
\hline Laetiporus sulphureus (Lat.) & 20 & 5.04 & 4.91 & 4.81 & 4.26 \\
\hline Butyriboletus regius (Lat.) & 20 & 10.99 & 10.65 & 10.62 & 9.4 \\
\hline Leccinum (Lat.) & 20 & 7.86 & 7.72 & 7.62 & 6.84 \\
\hline Russula Pers. (Lat.) & 20 & 11.18 & 10.75 & 10.68 & 9.49 \\
\hline Boletus edulis (Lat.) & 20 & 11.41 & 11.08 & 11.16 & 9.74 \\
\hline Amanita rubescens (Lat.) & 20 & 6.59 & 6.35 & 6.32 & 5.78 \\
\hline Leccinum scabrum (Lat.) & 20 & 4.16 & 4.09 & 4.01 & 3.5 \\
\hline Leccinum aurantiacum (Lat.) & 20 & 10.32 & 9.99 & 9.83 & 8.86 \\
\hline Armillaria mellea (Lat.) & 20 & 0.074 & 0.073 & 0.073 & 0.064 \\
\hline
\end{tabular}

The source is based on our own research findings

In Option 1 (Table 1) the concentration of zinc in mushrooms decreased from 1.01 to 1.04 times, in particular, in Cantharêllus cibārius (Lat.) - by 1.02 times, in Gyroporus cyanescens (Lat.) - by 1.01 times, in Laetiporus sulphureus (Lat.) - by 1.02 times, in Butyriboletus regius (Lat.) - by 1.03 times, in Leccinum (Lat.) - by 1.01 times, in Russula Pers. (Lat.) - by 1.04 times, in Boletus edulis (Lat.) - by 1.02 times, in Amanita rubescens (Lat.) - by 1.03 times, in Leccinum scabrum (Lat.) - by 1.01 times, in Leccinum aurantiacum (Lat.) - by 1.03 times and in Armillaria mellea (Lat.) - by 1.01 times.

In Option 2 the concentration of zinc in the mushrooms decreased from 1.01 to 1.04 times, in particular, in Cantharēllus cibārius (Lat.) and Gyroporus cyanescens (Lat.) - by 1.02 times, in Laetiporus sulphureus (Lat.) - by 1.04 times, in Butyriboletus regius (Lat.) and Leccinum (Lat.) - by 1.03 times, in Russula Pers. (Lat.) - by 1.04 times, in Boletus edulis (Lat.) - by 1.02 times, in Amanita rubescens (Lat.)- by 1.04 times, in Leccinum scabrum (Lat.) - by 1.03 times, in Leccinum aurantiacum (Lat.) - by 1.04 times and in Armillaria mellea (Lat.)- by 1.01 times.

In Option 3 the concentration of zinc in mushrooms decreased from 1.13 to 1.18 times, in particular, in Cantharēllus cibārius (Lat.) - by 1.13 times, in Gyroporus cyanescens (Lat.) - by 1.16 times, in Laetiporus sulphureus (Lat.) - by 1.18 times, in Butyriboletus regius (Lat.) - by 1.16 times, in Leccinum (Lat.) - by 1.14 times, in Russula Pers. (Lat.) and Boletus edulis (Lat.) - by 1.17 times, in Amanita rubescens (Lat.) - by 1.14 times, in Leccinum scabrum (Lat.) - by 1.18 times, in Leccinum aurantiacum (Lat.) - by 1.16 times and in Armillaria mellea (Lat.) - by 1.15 times (Fig. 1). 


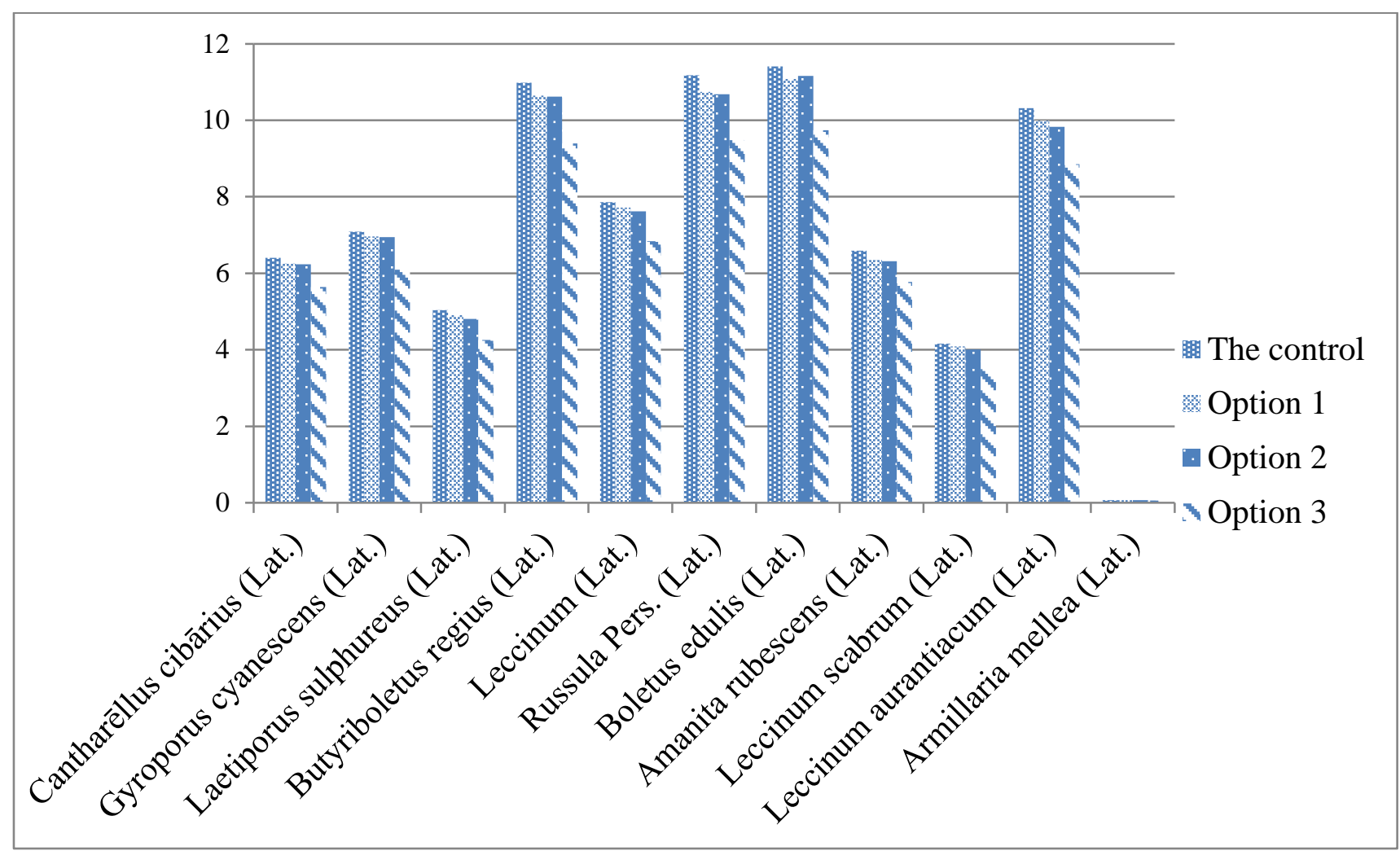

Fig. 1 Concentration of zinc in mushrooms

The source is based on our own research findings

In Option 1 (Table 2) the concentration of copper in mushrooms decreased from 1.0 to 1.2 times, in particular, in Cantharēllus cibārius (Lat.) - by 1.03 times,

Table 2

Copper concentration in mushrooms, $\mathrm{mg} / \mathrm{kg}$

\begin{tabular}{|c|c|c|c|c|c|}
\hline Kind of mushrooms & MPC & $\begin{array}{c}\text { The } \\
\text { control }\end{array}$ & Option 1 & Option 2 & Option 3 \\
\hline Cantharellus cibārius (Lat.) & 10 & 0.32 & 0.31 & 0.26 & 0.25 \\
\hline Gyroporus cyanescens (Lat.) & 10 & 0.63 & 0.62 & 0.51 & 0.49 \\
\hline Laetiporus sulphureus (Lat.) & 10 & 0.06 & 0.05 & 0.05 & 0.05 \\
\hline Butyriboletus regius (Lat.) & 10 & 0.18 & 0.17 & 0.15 & 0.14 \\
\hline Leccinum (Lat.) & 10 & 0.25 & 0.24 & 0.2 & 0.2 \\
\hline Russula Pers. (Lat.) & 10 & 0.64 & 0.62 & 0.51 & 0.51 \\
\hline Boletus edulis (Lat.) & 10 & 0.26 & 0.25 & 0.21 & 0.21 \\
\hline Amanita rubescens (Lat.) & 10 & 0.16 & 0.15 & 0.13 & 0.13 \\
\hline Leccinum scabrum (Lat.) & 10 & 0.70 & 0.68 & 0.57 & 0.55 \\
\hline Leccinum aurantiacum (Lat.) & 10 & 0.14 & 0.13 & 0.12 & 0.11 \\
\hline Armillaria mellea (Lat.) & 10 & 2.80 & 2.72 & 2.25 & 2.17 \\
\hline
\end{tabular}

The source is based on our own research findings

in Gyroporus cyanescens (Lat.) - by 1.01 times, in Laetiporus sulphureus (Lat.) - by 1.2 times, in Butyriboletus regius (Lat.) - by 1.05 times, in Leccinum (Lat.) - by 1.04 times, in Russula Pers. (Lat.) - by 1.0 times, in Boletus edulis (Lat.) - by 1.04 times, in Amanita rubescens (Lat.) - by 1.06 times, in Leccinum scabrum (Lat.) - by 1.02 
times, in Leccinum aurantiacum (Lat.) - by 1.07 times and in Armillaria mellea (Lat.) - by 1.02 times.

In Option 2 the concentration of copper in mushrooms decreased from 1.16 to 1.25 times, in particular, in Cantharēllus cibārius (Lat.) and Gyroporus cyanescens (Lat.) - by 1.23 times, in Laetiporus sulphureus (Lat.) and Butyriboletus regius (Lat.) - by 1.2 times, in Leccinum (Lat.) and Russula Pers. (Lat.) - by 1.25 times, in Boletus edulis (Lat.) and Amanita rubescens (Lat.) - by 1.23 times, in Leccinum scabrum (Lat.) - by 1.22 times, in Leccinum aurantiacum (Lat.) - by 1.16 times and in Armillaria mellea (Lat.) - by 1.24 times.

In Option 3 the concentration of copper in mushrooms decreased from 1.2 to 1.29 times, in particular, in Cantharēllus cibārius (Lat.) and Gyroporus cyanescens (Lat.) - by 1.28 times, in Laetiporus sulphureus (Lat.) - by 1.2 times, in Butyriboletus regius (Lat.) - by 1.28 times, in Leccinum (Lat.) and Russula Pers. (Lat.) - by 1.25 times, in Boletus edulis (Lat.) and Amanita rubescens (Lat.) - by 1.23 times, in Leccinum scabrum (Lat.) and Leccinum aurantiacum (Lat.) - by 1.27 times, and in Armillaria mellea (Lat.) - by 1.29 times (Fig. 2).

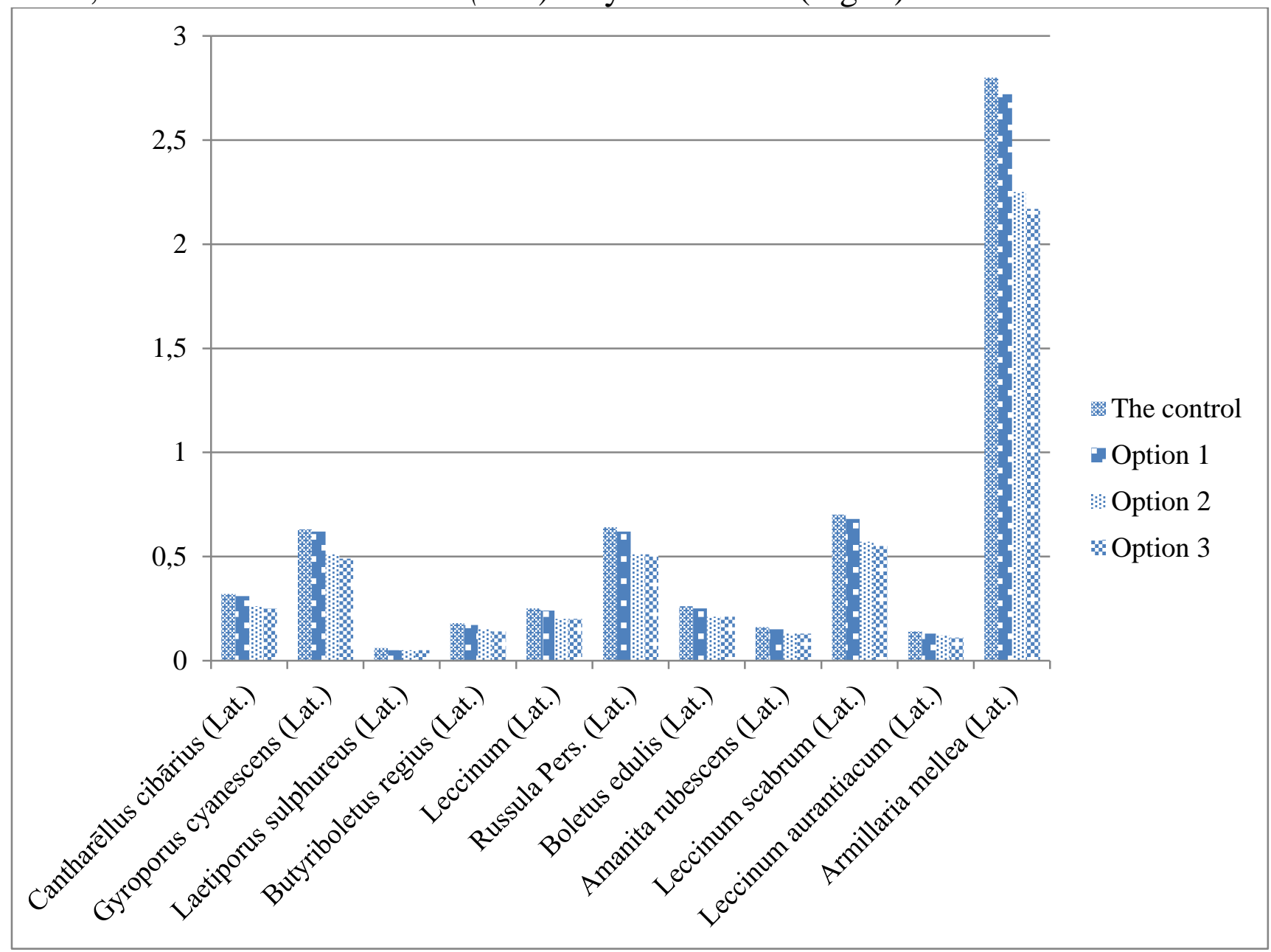

Fig. 2. Concentration of copper in mushrooms

The source is based on our own research findings 
Lead concentration in mushrooms, $\mathrm{mg} / \mathrm{kg}$

\begin{tabular}{|l|c|c|c|c|c|}
\hline \multicolumn{1}{|c|}{ Kind of mushrooms } & MPC & $\begin{array}{c}\text { The } \\
\text { control }\end{array}$ & Option 1 & Option 2 & Option 3 \\
\hline Cantharēllus cibārius (Lat.) & 0.5 & 0.21 & 0.19 & 0.11 & 0.17 \\
\hline Gyroporus cyanescens (Lat.) & 0.5 & 0.22 & 0.20 & 0.11 & 0.17 \\
\hline Laetiporus sulphureus (Lat.) & 0.5 & 0.27 & 0.24 & 0.15 & 0.22 \\
\hline Butyriboletus regius (Lat.) & 0.5 & 0.24 & 0.21 & 0.13. & 0.19 \\
\hline Leccinum (Lat.) & 0.5 & 0.28 & 0.25 & 0.15 & 0.22 \\
\hline Russula Pers. (Lat.) & 0.5 & 0.21 & 0.18 & 0.11 & 0.17 \\
\hline Boletus edulis (Lat.) & 0.5 & 0.23 & 0.21 & 0.12 & 0.18 \\
\hline Amanita rubescens (Lat.) & 0.5 & 0.27 & 0.24 & 0.15 & 0.21 \\
\hline Leccinum scabrum (Lat.) & 0.5 & 0.26 & 0.23 & 0.14 & 0.21 \\
\hline Leccinum aurantiacum (Lat.) & 0.5 & 0.22 & 0.20 & 0.12 & 0.18 \\
\hline Armillaria mellea (Lat.) & 0.5 & 0.29 & 0.26 & 0.16 & 0.23 \\
\hline
\end{tabular}

The source is based on our own research findings

In Option 1 (Table 3) the concentration of lead in mushrooms decreased from 1.09 to 1.16 times, in particular, in Cantharēllus cibārius (Lat.) - by 1.1 times, in Gyroporus cyanescens (Lat.) - by 1.1 times, in Laetiporus sulphureus (Lat.) - by 1.12 times, in Butyriboletus regius (Lat.) - by 1.14 times, in Leccinum (Lat.) - by 1.12 times, in Russula Pers. (Lat.) - by 1.16 times, in Boletus edulis (Lat.) - by 1.09 times, in Amanita rubescens (Lat.) - by 1.12 times, in Leccinum scabrum (Lat.) - by 1.13 times, in Leccinum aurantiacum (Lat.) - by 1.1 times and in Armillaria mellea (Lat.) - by 1.11 times.

In Option 2 the concentration of lead in mushrooms decreased from 1.8 to 2.0 times, in particular, in Cantharēllus cibārius (Lat.) - by 1.9 times, in Gyroporus cyanescens (Lat.) - by 2.0 times, in Laetiporus sulphureus (Lat.) - by 1.8 times, in Butyriboletus regius (Lat.) - by 1.84 times, in Leccinum (Lat.) - by 1.86 times, in Russula Pers. (Lat.) - by 1.9 times, in Boletus edulis (Lat.) - by 1.91 times, in Amanita rubescens (Lat.) - by 1.8 times, in Leccinum scabrum (Lat.) - by 1.85 times, in Leccinum aurantiacum (Lat.) - by 1.83 times and in Armillaria mellea (Lat.) - by 1.81 times.

In Option 3 the concentration of lead in mushrooms decreased from 1.22 to 1.28 times, in particular, in Cantharēllus cibārius (Lat.) - by 1.23 times, in Gyroporus cyanescens (Lat.) - by 1.29 times, in Laetiporus sulphureus (Lat.) - by 1.22 times, in Butyriboletus regius (Lat.) - by 1.26 times, in Leccinum (Lat.) - by 1.27 times, in Russula Pers. (Lat.) - by 1.23 times, in Boletus edulis (Lat.) - by 1.27 times, in Amanita rubescens (Lat.) - by 1.28 times, in Leccinum scabrum (Lat.) - by 1.23 times, in Leccinum aurantiacum (Lat.) - by 1.22 times and in Armillaria mellea (Lat.) - by 1.26 times (Fig. 3). 


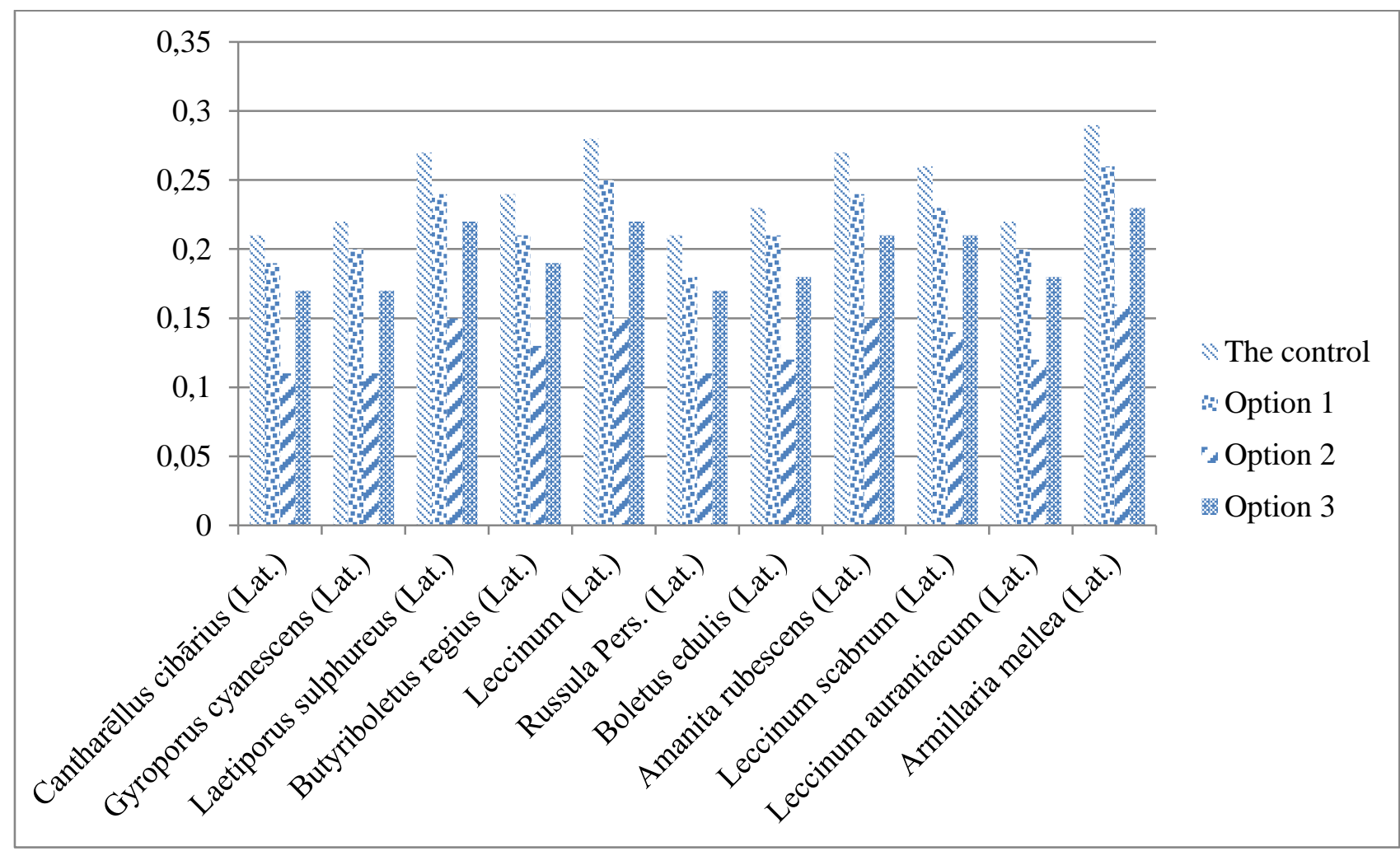

Fig. 3. Concentration of lead in mushrooms

The source is based on our own research findings

In Option 1 (Table 4) the concentration of cadmium in mushrooms decreased from 1.08 to 1.2 times, in particular, in Cantharēllus cibārius (Lat.)- by 1.2 times, in Gyroporus cyanescens (Lat.) - by 1.14 times, in Laetiporus sulphureus (Lat.) -1.15 times, in Butyriboletus regius (Lat.) - by 1.16 times, in Leccinum (Lat.) - by 1.13

\section{Cadmium concentration in mushrooms, $\mathrm{mg} / \mathrm{kg}$}

\begin{tabular}{|l|c|c|c|c|c|}
\hline \multicolumn{1}{|c|}{ Kind of mushrooms } & MPC & $\begin{array}{c}\text { The } \\
\text { control }\end{array}$ & Option 1 & Option 2 & Option 3 \\
\hline Cantharēllus cibārius (Lat.) & 0.1 & 0.06 & 0.05 & 0.03 & 0.04 \\
\hline Gyroporus cyanescens (Lat.) & 0.1 & 0.16 & 0.14 & 0.09 & 0.12 \\
\hline Laetiporus sulphureus (Lat.) & 0.1 & 015 & 0.13 & 0.08 & 0.12 \\
\hline Butyriboletus regius (Lat.) & 0.1 & 0.14 & 0.12 & 0.07 & 0.11 \\
\hline Leccinum (Lat.) & 0.1 & 0.17 & 0.15 & 0.09 & 0.13 \\
\hline Russula Pers. (Lat.) & 0.1 & 0.65 & 0.59 & 0.37 & 0.53 \\
\hline Boletus edulis (Lat.) & 0.1 & 0.17 & 0.15 & 0.09 & 0.14 \\
\hline Amanita rubescens (Lat.) & 0.1 & 0.15 & 0.13 & 0.08 & 0.12 \\
\hline Leccinum scabrum (Lat.) & 0.1 & 0.17 & 0.15 & 0.09 & 0.14 \\
\hline Leccinum aurantiacum (Lat.) & 0.1 & 0.13 & 0.12 & 0.07 & 0.10 \\
\hline Armillaria mellea (Lat.) & 0.1 & 0.17 & 0.15 & 0.09 & 0.13 \\
\hline
\end{tabular}

The source is based on our own research findings 
times, in Russula Pers. (Lat.) - by 1.1 times, in Boletus edulis (Lat.) - by 1.13 times, in Amanita rubescens (Lat.) - by 1.15 times, in Leccinum scabrum (Lat.) - by 1.13 times, in Leccinum aurantiacum (Lat.) - by 1.08 times and in Armillaria mellea (Lat.) - by 1.13 times.

In Option 2 the concentration of cadmium in mushrooms decreased from 1.75 to 2.0 times, in particular, in Cantharēllus cibārius (Lat.) - by 2.0 times, in Gyroporus cyanescens (Lat.) - by 1.77 times, in Laetiporus sulphureus (Lat.) - by 1.87 times, in Butyriboletus regius (Lat.) - by 2.0 times, in Leccinum (Lat.) - by 1.88 times, in Russula Pers. (Lat.) - by 1.75 times, in Boletus edulis (Lat.) - by 1.88 times, in Amanita rubescens (Lat.) - by 1.87 times, in Leccinum scabrum (Lat.) - by 1.88 times, in Leccinum aurantiacum (Lat.) - by 1.85 times and in Armillaria mellea (Lat.) - by 1.88 times.

In Option 3 the concentration of cadmium in mushrooms decreased from 1.21 to 1.5 times, in particular, in Cantharēllus cibārius (Lat.) - by 1.5 times, in Gyroporus cyanescens (Lat.) - by 1.33 times, in Laetiporus sulphureus (Lat.) - by 1.25 times, in Butyriboletus regius (Lat.) - by 1.27 times, in Leccinum (Lat.) - by 1.3 times, in Russula Pers. (Lat.) - by 1.22 times, in Boletus edulis (Lat.) - by 1.21 times, in Amanita rubescens (Lat.) - by 1.25 times, in Leccinum scabrum (Lat.) - by 1.21 times, in Leccinum aurantiacum (Lat.) - by 1.3 times and in Armillaria mellea (Lat.) - by 1.3 times (Fig. 4 ).

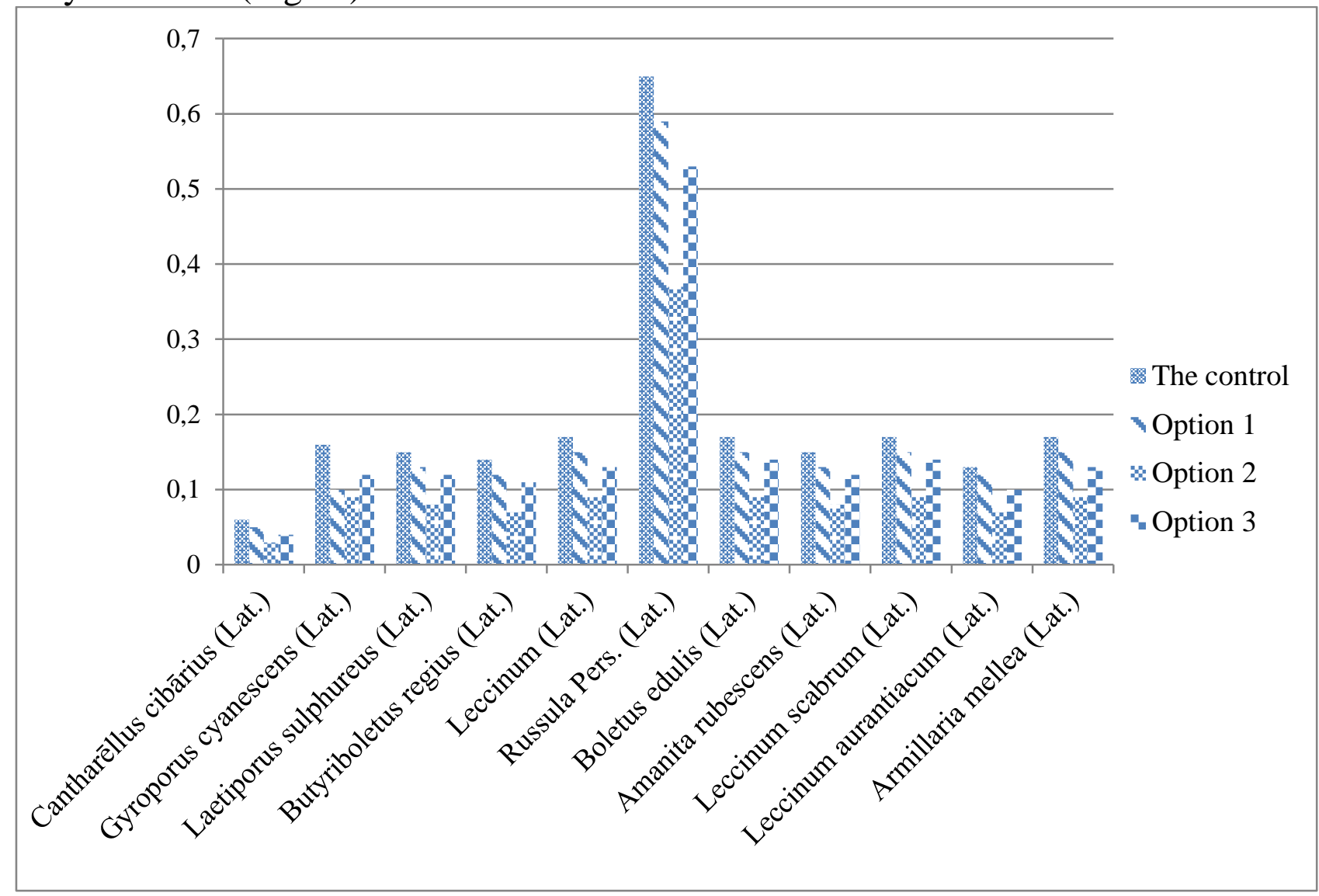

Fig. 4. Concentration of cadmium in mushrooms

The source is based on our own research findings 
Conclusions and prospects for further research. Summarizing the obtained results, it should be noted that the most effective way to reduce the concentration of lead and cadmium in mushrooms was the option of soaking and boiling mushrooms in the water without mineral residue. The most effective way to reduce the concentration of zinc and copper was Option 3, where distilled water was used. Thus, the concentration of zinc in mushrooms decreased from 1.01 to 1.04 times, the concentration of copper - from 1.0 to 1.2 times, the concentration of lead - from 1.09 to 1.16 times and the concentration of cadmium - from 1.08 to 1.2 times, when soaking and boiling them in tap water for 3 hours. When soaking and boiling mushrooms in the water without mineral residue, the concentration of zinc decreased from 1.01 to 1.04 times, the concentration of copper - from 1.16 to 1.25 times, the concentration of lead - from 1.8 to 2.0 times and the concentration of cadmium from 1.75 to 2.0 times. When soaking mushrooms and boiling them in distilled water, the concentration of zinc decreased from 1.13 to 1.18 times, the concentration of copper - from 1.2 to 1.29 times, the concentration of lead - from 1.22 to 1.28 times and the concentration of cadmium - from 1.08 to 1.2 times.

\section{Список використаної літератури}

1. Рибалова О.В., Коробкіна К.М. Новий підхід до оцінки забруднення грунтів важкими металами. Proceedings of the II International Scientific and Practical Conference «Topical problems of modern science». November 18, 2017. Warsaw, Poland. Vol. 5. p. 86-90.

2. Integrated Risk Information System (IRIS): U.S. Environmental Protection Agency (EPA). URL: http://www.epa. gov/iris

3. Калетник Н.Н., Кранов В.П., Орлов А.А. О радиологическом контроле в лесном хозяйстве Украины. Лесное хозяйство: межвуз. сб. науч. тр. 1995. № 1. C. 38-39.

4. Краснов В.П. Радіоекологія лісів Полісся України. Житомир : Вид-во «Волинь». 1998. 112 с.

5. Ландін В.П. Сучасна радіаційна ситуація в радіоактивно забруднених лісах України. Проблеми екології лісу і лісокористування на Поліссі України. Житомир: Вид- во «Волинь», 2002. Вип. 4 (10). С. 23-26.

6. Орлов О.О., Краснов В.П., Ландін В.П., Курбет Т.В., Заворотнюк Г.А. Вміст 137 Cs у продукції лісового господарства Житомирської області за даними 2002-2004 рр. Проблеми екології лісів і лісокористування на Поліссі України : зб. наук. пращь. Житомир : Вид-во «Волинь». 2005. Вип. 5 (11). С. 4961.

7. Колодій Т.В., Рябчук В.П. Хімічний склад плодових тіл окремих видів роду Russula s.f. gray. Науковий вісник НЛТУ Украӥни. Лісове та садовопаркове господарство, 2011. Вип. 21.4. С. 63-67.

8. Національна доповідь про стан техногенної та природної безпеки в Україні у 2017 році. URL: http: //www. dsns.gov.ua/.../Nacionalna-dopovidprostan-tehnogennoyi-ta-prirodnoyi-bez. 
9. Український науково-дослідний інститут цивільного захисту України. Статистика. Аналіз масиву карток обліку пожеж. URL: https://undicz.dsns. gov.ua/ua/Analiz-masivu-kartok-oblikupozhezh.html.

10. Грабовський О. В., Рошко В.Г., Ніколайчук О.І. Акумуляція важких металів грунтом та рослинними об’єктами в умовах антропогенного навантаження. Наук. вісник УждУ. Серія Біологія. Ужгород, 2000. № 8. С. 158160.

11. Кошкин Е. И. Физиология устойчивости сельскохозяйственных культур: монография. М. : Дрофа, 2010. 638 с.

12. Мельник Н. М., Морозова Т.В. Стан пилку деревних рослин у промислових зонах міста Чернівці. Наукові основи збереження біотичної різноманітності: тематичний зб. Ін-ту екологї Карпат НАН Украӥни. Львів : Ліга-Прес, 2006. Вип. 7. С. 54-60.

13. Регламент максимальних рівнів окремих забруднюючих речовин у харчових продуктах. Державні гігієнічні правила i норми. № 368. ДР-2013 [Чинний від 2013-05-13]. Київ. 2013. 10 с.

14. Врадій О.I. Вплив терміну вимочування у водно-сольовому розчині грибів на концентрацію в них цинку та міді. Вісник Уманського національного університету садівництвв. 2019. №2 . С.75-78.

\section{Список використаної літератури у транслітерації /References}

1. Rybalova O.V., Korobkina K.M. (2017). Novyi pidkhid do otsinky zabrudnennia gruntiv vazhkymy metalamy [A new approach to soil contamination by heavy metals]. Proceedings of the II International Scientific and Practical Conference «Topical problems of modern science». November 18. Warsaw, Poland. Vol. 5. 86-90. [in Polandian].

2. Integrated Risk Information System (IRIS): U.S. Environmental Protection Agency (EPA) (2019). URL: http://www.epa. gov/iris. [in USAan].

3. Kaletnyk N.N., Kranov V.P., Orlov A.A. (1995). O radyolohycheskom kontrole $\mathrm{v}$ lesnom khoziaistve Ukraynы [On radiological control in the forestry of Ukraine]. Lesnoe khoziaistvo: mezhvuz. sb. nauch. tr. - Forestry: interuniversity collection of scientific papers. № 1. 38-39. [in Ukrainian].

4. Krasnov V.P. (1998). Radioekolohiia lisiv Polissia Ukrainy [Radioecology of forests in Polissia of Ukraine]. Zhytomyr : Vyd-vo «Volyn». [in Ukrainian].

5. Landin V.P. (2002). Suchasna radiatsiina sytuatsiia V radioaktyvno zabrudnenykh lisakh Ukrainy. Problemy ekolohii lisu i lisokorystuvannia na Polissi Ukrainy [Current radiation situation in radioactively contaminated forests of Ukraine. Problems of forest ecology and forest management in Polissia of Ukraine.]. Zhytomyr : Vyd- vo «Volyn» - Zhytomyr: «Volyn» Publishing House, Issue. 4 (10). 23-26. [in Ukrainian]. 
6. Orlov O.O., Krasnov V.P., Landin V.P., Kurbet T.V. (2005). Vmist 137Cs u produktsii lisovoho hospodarstva Zhytomyrskoi oblasti za danymy 2002-2004 rr. [137Cs content in forestry products of Zhytomyr region according to 2002-2004]. (2005). / Problemy ekolohii lisiv i lisokorystuvannia na Polissi Ukrainy : zb. nauk. prats. Zhytomyr : Vyd-vo «Volyn» - Problems of forest ecology and forest management in the Polissya of Ukraine: a collection of scientific papers. Zhytomyr: «Volyn» Publishing House. Issue. 5 (11). 49-61. [in Ukrainian].

7. Kolodiy T.V., Riabchuk V.P. (2011). Khimichnyi sklad plodovykh til okremykh vydiv rodu Russula s.f. gray. [The chemical composition of the fruiting bodies of certain species of the genus Russula s.f. gray.]. Naukovyi visnyk NLTU Ukrainy. Lisove ta sadovo-parkove hospodarstvo - Scientific Bulletin of NLTU of Ukraine. Forestry and gardening, Issue. 21.4. 63-67. [in Ukrainian].

8. Natsionalna dopovid pro stan tekhnohennoi ta pryrodnoi bezpeky v Ukraini u 2017 rotsi (2017). [National report on the state of technogenic and natural security in Ukraine in 2017]. URL: http: //www. dsns.gov.ua/.../Nacionalna-dopovid-prostantehnogennoyi-ta-prirodnoyi-bez. [in Ukrainian].

9. Ukrainskyi naukovo-doslidnyi instytut tsyvilnoho zakhystu Ukrainy. Statystyka (2019). Analiz masyvu kartok obliku pozhezh [Ukrainian Research Institute of Civil Protection of Ukraine. Statistics. Analysis of arrays of fire accounting cards]. URL: https://undicz.dsns. gov.ua/ua/Analiz-masivu-kartokoblikupozhezh.html. [in Ukrainian].

10. Hrabovskyi A. V., Roshko V., Nykolaichuk A.Y. (2000). Akkumuliatsyia tiazhelыkh metallov pochvoi y rastytelnыmy obъektamy v uslovyiakh antropohennoi nahruzky [Accumulation of heavy metals by soil and plant objects under anthropogenic loading]. Nauk. vestnyk Uzhhorodskoho. Seryia Byolohyia - Scientific Bulletin of Uzhgorod State University. Series Biology. Uzhhorod, № 8. 158-160. [in Ukrainian].

11. Koshkyn E. Y. (2010). Fyzyolohyia ustoichyvosty selskokhoziaistvennыkh kultur [Physiology of crop sustainability]: monohrafyia. M.: Drofa. [in Russian].

12. Melnyk N. M., Morozova T.V. (2006). Sostoianye рыltsы drevesnыkh rastenyi $\mathrm{v}$ promushlennыkh zonakh horoda Chernovtsы [State of pollen of woody plants in industrial zones of Chernivtsi city]. Nauchnble osnovbl sokhranenyia byotycheskoho raznoobrazyia: tematycheskyi sb. Yn-ta эkolohyy Karpat NAN Ukraynbl - Scientific Basics of Biodiversity Conservation: Thematic Collection of the Institute of Ecology of the Carpathians of NAS of Ukraine. Lvov Lyha-Press. Issue. 7. 54-60. [in Ukrainian].

13.Rehlament maksymalnykh rivniv okremykh zabrudniuiuchykh rechovyn u kharchovykh produktakh (2013). [Regulation of maximum levels of certain contaminants in food]. Derzhavni hihiienichni pravyla i normy - State hygiene rules and regulations № 368. DR-2013 [Chynnyi vid 2013-05-13]. [in Ukrainian].

14.Vradiy O.I. (2019). Vplyv terminu vymochuvannia u vodno-solovomu rozchyni hrybiv na kontsentratsiiu $\mathrm{v}$ nykh tsynku ta midi [Influence of soaking time in 
aqueous salt solution of mushrooms on the concentration of zinc and copper in them]. Visnyk Umanskoho natsionalnoho universytetu sadivnytstva - Bulletin of the Uman National University of Horticulture. №2. 75-78. [in Ukrainian].

\section{АНОТАЦЯ \\ АНАЛІЗ ЕФЕКТИВНОСТІ ЗАСТОСУВАННЯ КУЛІНАРНОЇ ОБРОБКИ ГРИБІВ ДЛЯ ЗМЕНШЕННЯ В НИХ КОНЦЕНТРАЦЇ̈ ВАЖКИХ МЕТАЛІВ}

Дослідження кониентраиії важких металів проводились у науковій агрохімічній лабораторії кафедри екологї та охорони навколишнього середовищуа факультету агрономії та лісівництва Вінницьького національного аграрного університету. Концентрації $\mathrm{Cu}, \mathrm{Zn}$, $\mathrm{Pb}$ та Сd досліджуваних грибів визначали методом атомно-абсорбиійної спектрометрії після сухої мінералізації. Дослідження впливу кулінарної обробки на концентрацію важких металів у грибах проводили за такою схемою: 1. Контроль: гриби, очищені та промиті водопровідною водою; 2. Варіант 1: гриби замочують у водопровідній воді на 3 години $i$ варять у ній; 3. Варіант 2: гриби замочують у воді без залишків мінеральних речовин на 3 години і варять у ній; 4. Варіант 3: гриби замочують у дистильованій воді на 3 години $i$ варять у ній. Підсумовуючи отримані результати, слід зазначити, щуо найефективнішим способом зниження концеентрації свинцю та кадмію в грибах був варіант замочування та відварювання грибів у воді без залишків мінеральних речовин. Найефективнішим способом зниження концентрації ичинку та міді був варіант 3, де використовувалася дистильована вода. Досліджено вплив замочування та кипіння грибів у різних типах води. При замоченні та кип 'ятінні грибів у водопровідній воді протягом 3 годин виявлено, щзо концентрація цуинку в них знижується з 1,01 до 1,04 рази, концентраџія міді - з 1,0 до 1,2 рази, кониентрація свинцю - $~ 1,09$ до 1,16 рази і концентрація кадмію - від 1,08 до 1,2 рази. При замочуванні та кип'ятінні грибів у воді без залишку мінеральних речовин концентрація цуинку зменшилася з 1,01 до 1,04 рази, концентрація міді - з 1,16 до 1,25 рази, концентрація свинцюю - 3 1,8 до 2,0 рази і концентрачія кадмію - від 1,75 до 2,0 рази. При замочуванні грибів $i$ кип'ятінні їх у дистильованій воді концентраџія циннку змениилася з 1,13 до 1,18 разу, концентрація міді - 3 1,2 до 1,29 разу, концеентрація свинцүю - з 1,22 до 1,28 разу та концентрація кадмію - 3 1,08 в 1,2 рази.

Ключові слова: гриби, концеентрачія, ичинк, мідь, свинец̧ь, кадмій, дистильована вода, вода без мінерального залишку, водопровідна вода, переварювання грибів.

Табл. 4. Рис. 4. Літ. 14.

\section{АННОТАЦИЯ \\ АНАЛИЗ ЭФФЕКТИВНОСТИ ПРИМЕНЕНИЯ КУЛИНАРНОЙ ОБРАБОТКИ ГРИБОВ ДЛЯ СНИЖЕНИЯ В НИХ КОНЦЕНТРАЦИИ ТЯЖЕЛЫХ МЕТАЛЛОВ}

Исследовано влияние вымачивания и переваривания грибов в разных видах воды. Установлено, что в грибах концентрацчия цчинка, меди, свинц̧а и кадмия снизилась от 1,01 до 1,04 раза; от 1,0 до 1,2 раза; от 1,09 до 1,16 раза; от 1,08 до 1,2 раза соответственно при вымачивании и переваривании их в водопроводной воде в течение 3-х часов. При вымачивании и переваривании грибов в воде без минерального остатка конщентраџия цуинка, меди, свинща и кадмия снизилась от 1,01 до 1,04 раза; от 1,16 до 1,25 раза; от 1,8 до 2,0 раза; от 1,75 до 2,0 раза соответственно. При вылачивании грибов и переваривании их в дистиллированной воде конщентрация цуика, меди, свинца и кадмия снизилась от 1,13 до 1,18 раза; от 1,2 до 1,29 раза; от 1,22 до 1,28 раза; от 1,08 до 1,2 раза.

Ключевые слова: грибы, конщентрацчи, циинк, медь, свинец, кадмий, дистиллированная вода, вода без минерального остатка, водопроводная вода, переваривания грибов.

Табл. 4. Рис. 4. Лит. 14. 


\section{Інформація про автора}

Врадій Оксана Ігорівна - асистент кафедри екології та охорони навколишнього середовища Вінницького національного аграрного університету, (21008, м. Вінниця, вул. Сонячна, 3, e-mail: oksanavradii@gmail.com).

Врадий Оксана Игоревна - ассистент кафедры экологии и охраны окружающей среды Винницкого национального аграрного университета, (21008, г. Винница, ул. Солнечная, 3, e-mail: oksanavradii@gmail.com).

Vradiy Oksana Ihorivna - assistant of the Department of Ecology and Environmental Protection, Vinnytsia National Agrarian University (21008, Vinnytsia, 3, Soniachna St., e-mail: oksanavradii@gmail.com). 